\title{
PENGARUH DEWAN KOMISARIS, KOMISARIS INDEPENDEN, DAN KOMPENSASI DEWAN KOMISARIS DAN DIREKSI TERHADAP TINDAKAN AGRESIVITAS PAJAK PADA PERUSAHAAN MAKANAN DAN MINUMAN YANG TERDAFTAR DI BURSA EFEK INDONESIA PERIODE 2013-2016
}

\section{THE EFFECT OF THE BOARD OF COMMISSIONERS, INDEPENDENT COMMISSIONERS, AND COMPENSATION OF THE BOARD OF COMMISSIONERS AND BOARD OF IRECTORS ON TAX AGRESSIVITY MEASURES IN FOOD AND BEVERAGE COMPANIES LISTED IN INDONESIA STOCK EXCHANGE PERIOD 2013-2016}

\author{
Hanifah Hanim 1 , Fatahurrazak ${ }^{2}$ \\ ${ }^{1}$ Alumni Mahasiswa Fakultas Ekonomi Universitas Maritim Raja Ali Haji (Tanjungpinang) \\ 2Fakultas Ekonomi Universitas Maritim Raja Ali Haji (Tanjungpinang) \\ Email : faturajafatur@gmail.com
}

\begin{abstract}
ABSTRAK
Penelitian ini bertujuan untuk mengetahui pengaruh Dewan Komisaris, Komisaris Independen, Kompensasi Dewan Komisaris dan Direksi terhadap tindakan agresivitas pajak. Populasi dalam penelitian ini adalah laporan keuangan perusahaan perusahaan manufaktur sektor makanan dan minuman yang terdaftar di Bursa Efek Indonesia tahun 2013-2016. Sampel ditentukan dengan purposive sampling, sehingga diperoleh total sampel penelitian sebanyak 11 sampel. Jenis data yang yang digunakan adalah data sekunder yang diperoleh dari www.idx.co.id.Data dianalisis dengan menggunakan uji regresi linear berganda. Hasil penelitian ini menunjukkan bahwa Dewan Komisaris dan Kompensasi Dewan Komisaris dan Direksi berpengaruh terhadap tindakan agresivitas pajak.Sedangkan Komisaris Independen tidak berpengaruh terhadap tindakan agresivitas pajak.
\end{abstract}

Kata kunci : Dewan Komisaris, Komisaris Independen, Kompensasi Dewan Komisaris dan Direksi, Komite Audit dan Agresivitas Pajak.

\begin{abstract}
The aim of the research is to obtain find the effect of Commissioner, Independent Commissiner, compensation of Commisioner and Executive and Audit Committee towards the concentration on the tax aggressiveness on the manufactured companies sub sector food and beverage on the Stock Exchange from 2013-2016. The sample is determined by purposive sampling. The type of data used is used data from www.idx.co.id. Data were analyzed by using multiple linear regression test. The results of the study showed that Commissioner and compensation of Commissioner an Executive affect to the concentration on the tax aggressiveness and the Independent Commissioner don't affect to the concentration on the tax aggressiveness.
\end{abstract}

Keyword: Commissoner, Independent Commissioner, compensation of Commissioner and Executive, Audit Commitee, and Tax Agressiveness. 


\section{PENDAHULUAN}

Pajak merupakan kontribusi wajib kepada negara yang terutang oleh orang pribadi atau badan yang bersifat memaksa berdasarkan Undang-Undang, dengan tidak mendapatkan imbalan secara langsung dan digunakan untuk keperluan negara bagi sebesar-besarnya kemakmuran rakyat. Pajak merupakan salah satu sumber penerimaan utama suatu negara dalam rangka pembiayaan penyelenggaraan pemerintahan untuk penyediaan barang dan jasa publik serta pembangunan (Rahayu, 2014).

Penerimaan pajak mengalami peningkatan dari tahun ke tahun. Berdasarkan website resmi Dirjen Pajak realisasi penerimaan pajak sebagai berikut : Tahun 2013 Rp.995,2 triliun; Ttahun 2014 Rp.1.110,2 triliun; tahun 2015 Rp.1.294; tahun 2016 Rp.1.355,203 triliun.

Pemerintah secara rutin melakukan reformasi pajak dimana tahun 2008 pemerintah memberikan insentif berupa penurunan tarif Pajak Penghasilan menjadi $28 \%$ pada tahun 2008 dan akan menjadi $25 \%$ pada tahun fiskal 2010 . Dengan adanya reformasi perpajakan tentunya juga dirancang agar wajib pajak tidak melakukan manajemen pajak secara agresif. Agresivitas pajak dapat timbul karena adanya perbedaan kepentingan antara wajib pajak dan pemerintah. Pemerintah memerlukan dana untuk untuk membiayai penyelenggaraan kegiatan pemerintah yang berasal sebagian besar dari pajak. Namun, disisi lain perusahaan sebagai wajib pajak menganggap pajak sebagai biaya karena dengan membayar pajak berarti mengurangi jumlah laba bersih yang akan diterima (Sabrina, 2013).

Beberapa penelitian menjelaskan definisi agresivitas. menurut Frank, Lynch, dan Rego (2009) dalam Novitasari (2017), agresivitas pajak adalah suatu tindakan merekayasa pendapatan kena pajak yang dirancang melalui tindakan perencanaan pajak baik menggunakan cara yang tergolong secara legal (tax avoindance) atau ilegal (tax evasion). Semakin besar penghematan pajak yang dilakukan oleh perusahaan, maka perusahaan tersebut dianggap semakin agresif terhadap pajak. Dalam penelitian ini, agresivitas pajak diukur menggunakan ETR (effective tax rate), karena perusahaan-perusahaan yang menghindari pajak dengan mengurangi penghasilan kena pajak mereka dengan tetap menjaga laba akuntansi keuangan sehingga akan memiliki nilai ETR yang akan rendah (Sabrina, 2013).

Berdasarkan adanya perbedaan penelitian-penelitian sebelumnya maka peneliti menganalisis kembali bagaimana pengaruh Dewan Komisaris, Komisaris Independen, kompensasi Dewan Komisaris dan Direksi terhadap tindakan agresivitas pajak pada perusahaan manufaktur sub sektor makanan dan minuman yang terdaftar di Bursa Efek Indonesia periode 2013-2016. Penelitian ini menggunakan perusahaan manufaktur sub sektor makanan dan minuman karena peneliti menghindari terjadinya bias terhadap hasil penelitian yang disebabkan perbedaan karakteristik perusahaan. Alasan memilih perusahaan makanan dan minuman sebagai objek penelitian karena sektor industri makanan dan minuman merupakan salah satu sektor usaha yang akan terus mengalami pertumbuhan. Seiring dengan meningkatnya pertumbuhan jumlah penduduk dan kondisi ekonomi di Indonesia saat ini yang tidak terlalu bagus, permintan konsumen akan makanan dan minuman ini tidak terpengaruh.

Berdasarkan urutan latar belakang diatas, maka penelitian ini mengambil judul "Pengaruh Dewan Komisaris, Komisaris Independen, Dan Kompensasi Dewan Komisaris Dan Direksi Terhadap Tindakan Agresivitas Pajak Pada Perusahaan Manufaktur Sub Sektor Makanan Dan Minuman Yang Terdaftar Di Bursa Efek Indonesia Periode 2013-2016".

Berdasarkan uraian diatas, maka rumusan masalah sebagai berikut: 1. Apakah Dewan Komisaris berpengaruh terhadap tindakan agresivitas pajak?; 2. Apakah Komisaris Independen 
berpengaruh terhadap tindakan agresivitas pajak? 3. Apakah kompensasi Dewan Komisaris dan Direksi berpengaruh terhadap tindakan agersivitas pajak? ; 4. Apakah Dewan Komisaris, Komisaris Independen, dan Kompensasi Dewan Komisaris dan Direksi berpengaruh secara bersama-sama terhadap agresivitas pajak?

\section{LANDASAN TEORI}

Pajak

Pajak adalah suatu kewajiban atau beban yang harus dipenuhi kewajibannya oleh wajib pajak baik orang pribadi maupun perusahaan. Perusahaan menganggap pajak merupakan suatu beban yang harus diminimalkan agar memperoleh laba yang tinggi atau kas yang dikeluarkan tidak terlalu besar, sehingga pihak manajemen perusahaan sering melakuakan cara-cara tertentu untuk mengurangi beban pajaknya, baik yang diperbolehkan maupun yang dilarang undangundang perpajakan yang berlaku.

Definisi pajak menurut Undang-Undang Republik Indonesia Nomor 28 Tahun 2007 pasal 1 , yaitu kontribusi wajib pajak negara yang terutang oleh orang pribadi atau badan yang bersifat memaksa berdasarkan undang-undang, dengan tidak mendapatkan imbalan secara langsung dan digunakan untuk keperluan negara bagi sebesar-besarnya kemakmuran rakyat. Pengertian pajak menurut Prof. Dr. Rochmat Soemitro, S.H (Mardiasmo, 2008) pajak adalah iuran rakyat kepada kas negara (peralihan kas ke sektor pemerintahan berdasarkan Undang-Undang) dapat dipaksakan dengan tiada mendapat timbal balik yang langsung dapat ditunjukkan dan digunakan untuk membiayai pengeluaran umum.

Menurut Andriani, pajak dalam Mardiasmo (2008), merupakan iuran kepada negara (yang dapat dipaksakan) yang terutang oleh wajib pajak yang membayarnya menurut peraturanperaturan, dengan tidak mendapat prestasi kembali, yang langsung dapat ditunjuk, dan yang gunanya adalah untuk mebiayai pengeluaran-pengeluaran umum yang berhubungan dengan tugas negara untuk menyelenggarakan pemerintahan. Dari definisi-definisi tersebut dapat disimpulkan bahwa pajak adalah iuran yang dibayar wajib pajak yang bersifat wajib dan memaksa yang akan dikenakan sanksi apabila tidak dipenuhi sesuai dengan peraturan perundang-undangan perpajakan yang berlaku di Indonesia.

\section{Tindakan Agresivitas Pajak (Tax Aggressivness)}

Agresivitas pajak merupakan hal yang sekarang umum terjadi dikalangan perusahaanperusahaan besar diseluruh dunia. Tindakan ini bertujuan untuk meminimalkan pajak perusahaan yang kini menjadi perhatian publik karena tidak sesuai dengan harapan masyarakat dan juga merugikan pemerintah.

Menurut Frank, et, al (2009) dalam Husodo (2017), tindakan agresivitas pajak adalah tindakan yang dilakukan untuk mengurangi pendapatan kena pajak melalui perencanaanpajak baik secara legal (tax avoidance) maupun illegal (tax evasion). Sedangkan menurut Solihin (2017) tindakan agresivitas merupakan suatu pengelolaan yang ditujukan untuk menurunkan laba kena pajak melalui perencanaan pajak baik memakai cara yang termasuk tax evasion atau tidak. Tax Evasion adalah usaha yang dilakukan oleh wajib pajak untuk mengurangi beban pajaknya dengan cara-cara yang tidak mematuhi peraturan perpajakan. Walau tidak semua tindakan yang 
dilakukan melanggar hukum, namunsemakin banyak celah yang digunakan perusahaan maka perusahaan tersebut semakin agresif.

Penelitian ini menggunakan perhitungan effective tax rate (ETR) karena ETR adalah proksi yang paling banyak digunakan dalam literatur dan nilai rendah dari ETR dapat menjadi indikator adanya agresivitas pajak. Secara keseluruhan, perusahaan-perusahaan yang menghindari pajak perusahaan dapat mengurangi penghasilan kena pajak mereka dengan tetap menjaga laba akuntansi keuangan dan memiliki nilai ETR yang lebih rendah. Maka dari itu, ETR dapat digunakan untuk mengukur agresivitas pajak.

\section{Keuntungan dan Kerugian dari Tindakan Agresivitas Pajak}

Tindakan agresivitas pajak dapt memberikan marginal benefit maupun marginal cost. Marginal benefit yang didapat adanya penghematan pajak (tax saving) yang signifikan bagi perusahaan sehingga porsi yang dinikmati oleh pemilik akan menjadi lebih besar. Kemudian dengan melakukan tindakan pajak agresivitas dapat memberikan keuntungan pada manajer baik secara langsung maupun tidak langsung. Manajer bisa mendapatkan kompensasi yang lebih tinggi atas kinerjanya yang menghasilkan beban pajak perusahaan yang harus dibayarkan menjadi lebih rendah. Selain itu manajer juga berkesempatan untuk mendapatkan keuntungan pribadi dengan melakukan rent extraction. Rent extraction adalah suatu tindakan manajer yang tidak memaksimalkan kepentingan pemilik, tindakan ini dapat berupa penyusunan laporan keuangan yang agresif, mengambil sumber daya atau asset perusahaan untuk kepentingan pribadi, maupun melakukan transaksi dengan pihak istimewa.

Sedangkan marginal cost yang mungkin terjadi adalah penalti atau sanksi administrasi yang dikenakan oleh petugas pajak yang merupakan akibat dari kemungkinan dilakukannya audit dan ditemukannya kecurangan-kecurangan di bidang perpajakan pada perusahaan. Jika kecurangan-kecurangan tersebut ditemukan ketika dilakukan pemeriksaan maka akan berpotensi memunculkan biaya-biaya non pajak lainnya yang tentu saja dapat merugikan perusahaan dan merusak reputasi perusahaan. Salah satu contohnya adalah menurunnya harga saham perusahaan. Penurunan harga saham ini adalah sebagai akibat adanya anggapan dari pemegang saham bahwa tindakan pajak agresif yang dilakukan oleh manajer merupan tindakan rent extraction yang dapat merugikan pemegang saham (Fahriani, 2016)

\section{Dewan Komisaris}

Menurut FCGI (Forum for Corporate Governance in Indonesia), Dewan Komisaris memegang peranan yang sangat penting dalam perusahaan, terutama dalam pelaksanaan Corporate Governance. Menurut UUPT No. 40 tahun 2007, mendefinisikan Dewan Komisaris adalah organisasi peseroan yang bertugas mengawasi pengawasan secara umum dan atau khusus sesuai dengan anggaran dasar dan memberi nasehat kepada direksi. Indonesia mengadopsi two tier system, karena Indonesia memisahkan kewenangan perusahaan dan pengawasan yang selama ini dikenal dengan Direksi dan Dewan Komisaris. Dalam hal ini Direksi lebih berwenang menjalankan pengurusan perusahaan sedangkan Dewan Komisaris lebih bersifat melakukan pengawasan.

OECD (Organisation for Economic Coperation and Development) adalah organisasi multi negara yang didirikan untuk mempererat kerjasama dan pembangunan ekonomi antar negara 
demi mewujudkan stabilitas perekonomian yang berkelanjutan.Menurut OECD (Organisation for Economic Coperation and Development), tanggung jawab anggota dewan yaitu:

1. Anggota dewan harus bertindak berdasarkan informasi yang lengkap, dengan itikad yang baik, dengan ketelitian dan kepedulian, dan untuk kepentingan perusahaan dan pemegang saham.

2. Dimana keputuhan dewan dapat mempengaruhi kelompok pemegang saham yang berbeda, dewan harus memperlakukan semua pemegang sahm secara adil.

3. Dewan Komisaris harus menerapkan standar etika yang tinggi. Dimana harus mempertimbangkan kepentingan stakehorders.

4. Dewan Komisaris harus memenuhi fungsi utama teretntu, termasuk:

a) Meninjau dan membimbing strategi perusahaan, rencana utama dari tindakan, kebijakan resiko, anggaran tahunan dan rencana usaha, menetapkan sasaran kinerja, melakukan pengawasan kinerja perusahaan, dan mengawasi pengeluaranmodal utama, akuisisi dan divestasi.

b) Memantau efektivitas praktik tata kelola perusahaan dan membuat perubahan yang diperlukan.

c) Memilih, memberikan kompensasi, mengawasi dan bila perlu, mengganti eksekutif kunci dan mengawasi perencanaan suksesor tersebut.

d) Menyelaraskan remunerasi untuk eksekutif dan dewan dengan kepentingan jangka panjang perusahaan dan pemegang saham.

e) Memastikan transparansi nominasi dewan dan proses pemilu.

f) Mengawasi dan menangani potensi konflik kepentingan dari anggota dewan, manajemen dan pemegang saham, termasuk penyalahgunaan asset perusahaan dan penyalahgunaan dalam transaksi pihak yang memiliki hubungan istimewa.

g) Memastikan integritas akuntansi perusahaan dan sistem pelaporan keuangan, termasuk audit independen, dan bahwa sistem kontrol yang tepat telah dilakukan, khususnya sistem untuk manajemen risiko, pengendalian keuangan dan operasional, dan kepatuhan terhadap hukum dan standar yang relevan.

h) Mengawasi proses pengungkapan dan komunikasi.

5. Dewan harus dapat melakukan penilaian yang independen dan objektif dalam hubungan perusahaan.

a) Dewan harus mempertimbangkan untuk menugaskan cukup banyak anggota dewan non-eksekutif yang mampu menggunakan penilaian yang independen untuk tugas yang memiliki potensi konflik kepentingann.

b) Ketika dewan komite ditetapkan, mandata mereka, komposisi dan prosedur kerja harus didefinisikan dengan baik dan diungkapkan oleh dewan.

c) Anggota dewan harus dapat berkomitmen terhadap tanggung jawab mereka.

6. Untuk memenuhi tanggung jawab mereka, anggota dewan harus memiliki akses untuk informasi yang akurat, relevan dan tepat waktu.

\section{Komisaris Independen}

Komisaris Independen merupakan anggota Dewan Komisaris yang berasal dari luar manajemen perusahaan dan bukan merupakan pegawai perusahaan tersebut tapi berurusan langsung dengan organisasi dalam perusahaan. Perusahaan mengangkat Komisaris Independen untuk untuk mengawasi bagaimana organisasi dalam perusahaan dijalankan dan dapat menjadi penengah antara Komisaris dalam dan pihak pemegang saham apabila terjadi konflik. Komisaris 
Independen dipercayai menjadi penengah diantara kedua belahpihak karena bersikap objektif dan memiliki risiko yang kecil dalam konflik internal.

Berdasarkan Peraturan Otoritas Jasa Keuangan Nomor 33/PJOK.04/2014 tentang Direksi dan Dewan Komisaris Emiten atau Perusahaan Publik, menyatakan bahwa Komisaris Independen wajib memenuhi persyaratan sebagai berikut:

1. bukan merupakan orang yang bekerja atau mempunyai wewenang dan tanggung jawab untuk merencenakan, memimpin, mengendalikan, atau mengawasi kegiatan Emiten atau Perusahaan Publik tersebut dalam waktu 6 (enam) bulan terakhir, kecuali untuk pengangkatan kembali sebagai sebagai Komisaris Independen Emiten atau Perusahaan Publikpada periode berikutnya;

2. tidak mempunyai saham baik langsung maupun tidak langsung pada Emiten atau Perusahaan Publik tersebut;

3. tidak mempunyai hubungan Afiliasi dengan Emiten atau Perusahaan Publik, anggotaDewan Komisaris, anggota Direksi, atau pemegang saham utama Emiten atau Perusahaan Publik tersebut; dan

4. tidak memiliki hubungan usaha baik langsung maupun tidak langsung yng berkaitan dengan kegiatan usaha Emiten atau Perusahaan Publik tersebut.

Sedangkan berdasarkan peraturan Bursa Efek Indonesia (BEI) Nomor Kep-305/BEJ/072004 perusahaan harus memiliki Komisaris Independen sekurang-kurangnya 30\% (tiga puluh persen) dari jajaran anggota Dewan Komisaris yang dapat dipilih terlebih dahulu melalui RUPS sebelum pencatatan dan mulai efektif bertindak sebagai komisaris indepenen setelah saham perusahaan tercatat.

Komisaris Independen mempunyai peran yang cukup berpengaruh terhadap tingkat perusahaan dalam membayar pajak. Menurut Suyanto (2012) dalam Ardyansyah (2014), semakin banyak jumlah Komisaris Independen maka pengawasan terhadap agen semakin ketat. Karena adanya pengawasan lebih dari Komisaris Independen maka diprediksi tingkat pajak efektifnya sesuai dengan semestinya. Komisaris Independen selalu mengawasi agar perusahaan mematuhi hukum dan peraturan yang berlaku.

\section{Kompensasi Dewan Komisaris dan Direksi}

Kompensasi yaitu umpan balik yang dibayarkan kepada karyawan (seperti: gaji, dII). Gaji merupakan salah satu hal yang penting bagi setiap karyawan yang bekerja di suatu perusahaan kemudian sesorang dapat memenuhi kebutuhan hidupnya. Karena dengan seseorang memperoleh gaji maka seseorang dapat memenuhi kebutuhan hidupnya.

Kompensasi dapat berupa gaji, bonus, tunjangan, atau tambahan penghasilan. Gaji adalah suatu pembayaran tetap, sementara bonus didasarkan pada pencapaian tujuan-tujuan kinerja untuk suatu periode. Gaji, bonus, tunjangan, atau tambahan penghasilan mencakup tunjangantunjangan khusus bagi karyawan, seperti bepergian, keanggotaan dalam suatu klub kebugaran, asuransi jiwa, tunjangan kesehatan, tiket untuk hiburan, dan bayaran-bayaran tambahan lainnya oleh perusahaan.

Hal berbeda dikemukakan oleh Muljani (2002) dalam Syoraya (2014) bahwa kompensasi dapat berupa imbalan ekstrinsik yang mencakup kompensasi langsung, kompensasi tidak langsung dan imbalan bukan uang. Kompensasi langsung antara lain adalah gaji pokok, upah lembur, pembayaran insentif, tunjangan, bonus; sedangkan yang termasuk kompensasi tidak langsung adalah jaminan sosial, asuransi, pensiun, pesangon, cuti kerja, pelatihan, dan liburan. 
Adapun imbalan bukan imbalan adalah kepuasan yang diterima karyawan dari pekerjaan itu sendiri atau dari lingkungan psikologis dan/atau fisik dimana karyawan bekerja. Termasuk imbalan bukan uang misalnya rasa aman, atau lingkungan kerja yang nyaman, pengembangan diri, fleksibilitas karier, peluang kenaikan penghasilan, simbol status, pujian dan pengakuan.

Kompensasi juga dapat berbentuk finansial maupun non-finansial. Dalam bentuk finansial kompensasi dapat berupa gaji, upah, komisi, asuransi karyawan, bentuk sosial karyawan, tunjangan dan sebagainya. Sedangkan dalam bentuk non-finansial kompensasi dapat berbentuk tugas-tugas yang menarik, fasilitas kerja yang mewah dan memadai, posisi kerja, pengakuan, pencapaian tujuan, serta lingkungan yang mendukung.

Pemilik perusahaan dan pihak manajemen antar perusahaan memiliki jumlah kompensasi berbeda-beda. Besarnya kompensasi ini umumnya didasarkan pada informasi keuangan yang dikeluarkan oleh perusahaan yang dapat berupa informasi laba bersih atau juga dapat berupa harga saham (Scoot, 2006 dalam Santoso 2014).

Penelitian yang dilakukan oleh 1. Fadli (2013) dengan judul Pengaruh Likuiditas, leverage, komisaris independen, manajemen laba dan kepemilikan institusional terhadap Agresivitas Pajak Perusahaan, menyimpulkan Likuiditas, leverage, komisaris independen dan manajemen laba berpengaruh signifikan terhadap agresivitas pajak, namun Kepemilikan institusional tidak berpengaruh; 2. Rahayu (2014) dengan judul Pengaruh kompensasi eksekutif, keterwakilan CFO wanita, dan karakteristik eksekutif terhadap Tindakan Pajak Agresif, menyimpulkan Kompensasi eksekutif dan karakteristik eksekutif berpengaruh positif terhadap tindakan pajak agresif, namun Keterwakilan CFO wanita tidak berpengaruh; 3. Eksandy (2017) dengan judul Pengaruh Komisaris Indepdenden, komite audit, dan kualitas audit terhadap Penghindaran pajak menyimpulkan Komisaris Independen dan kualitas audit berpengaruh postif, namun Komite audit tidak berpengaruh.

\section{Pengembangan Hipotesis}

\section{Pengaruh Dewan Komisaris terhadap Tindakan Agresivitas}

Dalam mengelola perusahaan peran Dewan Komisaris sangat diperlukan. Dewan Komisaris sangat diperlukan. Dewan Komisaris bertugas dan bertanggung jawab melakukan pengawasan dan memberikan nasihat kepada dewan direksi serta memastikan perusahaan melaksanakan good corporate governance.

Dewan Komisaris merupakan perwakilan dari pemegang saham, sehingga diharapkan Dewan Komisaris dapat memaksimalkan laba dengan mengurangi beban pajak perusahaan. Semakin besar jumlah Dewan Komisaris maka dimungkinkan akan semakin besar pula tindakan pajak agresif yang dilakuakan oleh perusahaan (Fahriani dan Priyadi, 2016). Kondisi ini dapat disebabkan karena sulitnya kooordinasi antar anggota dewan dan hal ini menghambat proses pengawasan yang harusnya menjadi tanggung jawab Dewan Komisaris. Pada akhirnya terjadi pula tindakan pajak agresif yang dilakukan oleh pihak manajemen.

H1: Diduga Dewan Komisaris berpengaruh terhadap tindakan agresivitas pajak.

\section{Pengaruh Komisaris Independen terhadap Tindakan Agresivitas Pajak}

UU Nomor 40 Tahun 2007 tentang Perseroan Terbatas menyebutkan bahwa Komisaris Independen diangkat berdasarkan keputusan RUPS dari pihak yang terafiliasi dengan pemegang saham utama, anggota Direksi atau anggota Dewan Komisaris lainnya. 
Komisaris Independen sebagai pengawas yang mendorong manajemen perusahaan dengan melakukan pengawasan terhadap manajemen perusahaan agar dalam menghasilkan laba berdasarkan aturan yang berlaku, karena pada dasarnya Komisaris Independen lebih melihat seberapa jauh manajemen taat kepada aturan dalam menghasilkan laba, salah satunya adalah mematuhi peraturan pajak yang berlaku dan meminimalisir adanya tindakan pajak agresif yang dilakukan oleh perusahaan. Semakin banyak jumlah Komisaris Independen maka pengawasan terhadap agen semakin ketat. Karena adanya pengawasan lebih dari Komisaris Independen maka diprediksikan tungkat pajak efektifnya sesuai dengan semestinya. Komisaris Independen selalu mengawasi agar perusahaan mematuhi hukum dan peraturan yang berlaku.

H2: Diduga Komisaris Independen berpengaruh terhadap tindakan agresivitas pajak.

\section{Pengaruh Kompensasi Dewan Komisaris dan Direksi terhadap Tindakan Agresivitas Pajak}

Tujuan dari kompensasi adalah untuk menyelaraskan antara kepentingan pemegang saham dengan kepentingan pengelola asset. Kompensasi dapat memeberikan insentif jangka panjang dengan menggunakan bentuk insentif stock option maupun memberikan insentif jangka pendek dengan menggunakan kompensasi dalam bentuk uang.

Sistem kompensasi yang baik dapat memberikan kontribusi yang signifikan terhadap keberhasilan bisnis (Rahayu, 2014). Sitem kompensasi membantu dalam memberi penguatan terhadap nilai-nilai kunci organisasi serta memfasilitasi pencapaian tujuan organisasi (Sutrisno dalam Rahayu, 2014). Kompensasi juga menjadi pendorong seseorang untuk bekerja karena berpengaruh terhadap moral dan disiplin tenaga. Kebijakan penetuan kompensasi salah satu cara yang dapat dilakukan dalam rangka mendorong peningkatan kinerja para eksekutif perusahaan dan bertanggung jawab untuk mengoptimalkan keuntungan pemilik saham. Semakin tinggi perusahaan memberikan kompensasi maka mendorong peningkatan kerja yang dapat meminimalisasi agresivitas pajak. Dengan pemberian kompensasi diharapkan pihak eksekutif dapat meningkatkan kinerja dengan pemberian kompensasi yang tepat.

H3: Diduga Kompensasi Dewan Komisaris dan Direksi berpengaruh terhadap tindakan agresivitas pajak.

H4: Diduga Dewan Komisaris, Komisaris Independen, dan Kompensasi Dewan Komisaris dan Direksi berpengaruh secara bersama-sama terhadap Tindakan Agresivitas Pajak.

\section{METODOLOGI PENELITIAN}

\section{Jenis dan Sumber Data Penelitian}

Jenis data yang digunakan dalam penelitian ini adalah data sekunder, yaitu data-data yang disediakan oleh pihak lain dan tidak berasal dari sumber langsung. Data yang diperoleh berupak laporan keuangan perusahaan manufaktur sub sektor makanan dan minuman yang dipublikasikan oleh Bursa Efek Indonesia (BEI) tahun 2013-2016. Populasi yang digunakan dalam penelitian ini adalah semua perusahaan manufaktur sub sektor makanan dan minuman yang dipublikasikan oleh Bursa Efek Indonesia (BEI).pengambilan sampel dilakukan dengan metode purposive sampling. Jumlah populasi 15 yang memenuhi kriteria sebanyak 11 perusahaan, maka data penelitian $11 \times 4$ tahun $=44$ data. 


\section{Metode analisis dan Hipotesis Penelitian}

Pengujian pertama dengan uji statistic deskriptif, kemudian pengujian asumsi klasik senagai salah satu syarat untuk bisa menggunakan persamaan regresi berganda, yaitu terpenuhinya uji asumsi klasik, meliputi normalitas, heteroskedastisitas, auto korelasi dan multikolinearitas. Selanjutnya pengujian untuk metode analisis yang digunakan untuk menguji variable bebas terhadap variable terikat dengan Uji t. Uji f dan Uji determinasi.

\section{Operasionalisasi Variabel Penelitian}

Variabel bebas adalah variabel yang mempengaruhi variabel lainnya. Independent variable dalam penelitian ini adalah adalah jumlah Dewan Komisaris, Komisaris Independen, kompensasi Dewan Komisaris, Komite Audit.

Variabel dependen adalah variabel yang dipengaruhi oleh variabel independen atau variabel bebas. Dalam penelitian ini variabel dependennya adalah agresivitas pajak (tax aggressiveness). agresivitas pajak (tax aggressiveness) diukur menggunakan proksi effective Tax Rate (ETR). Effective Tax Rate (ETR) adalah tingkat pajak efektif perusahaan. ETR dihitung dari beban pajak penghasilan dibagi dengan pendapatan sebelum pajak. Semakin baik nilaiEffective Tax Rate (ETR) ditandai semakin rendahnya nilai Effective Tax Rate perusahaan tersebut.

$$
\begin{aligned}
& \text { ETR }=\frac{\text { Beban Pajak Penghasilan }}{\text { Laba Sebelum Pajak }} \ldots . . . . . . . . . . . . . . . \\
& \text { Keterangan: } \quad \text { ETR } \quad=\text { Tingkat Pajak Efektif }
\end{aligned}
$$

\section{Dewan Komisaris}

Penelitian-penelitian sebelumnya telah menunjukkan bahwa jumlah Dewan Komisaris mempengaruhi efektifitas pengawasan dalam perusahaan. Variabel ini diukur dengan secara numeral, yaitu dilihat jumlah nominal dari anggota yang tergabung dalam dewan komisaris sesuai penelitian Fahriani dan Priyadi (2016).

$$
\text { BOARD }=\sum \text { Seluruah Anggota DewanKomisaris }
$$

\section{Komisaris Independen}

Komisaris Independen merupakan komisaris yang berasal dari luar perusahaan yang tidak mempunyai saham dalam peruahaan dan tidak mempunyai hubungan baik langsung maupun tidak langsung berkaitan dengan kegiatan perusahaan. Skala yang digunakan untuk mengukur persentase komisaris independen yaitu dengan skala rasio, yaitu persentase jumlah anggota dewan komisaris independen dengan jumlah total anggota dewan komisaris. Pengukuran ini sesuai dengan pengukuran dalam penelitian yang dilakukan oleh Fadli (2013). Variabel ini dirumuskan sebagai berikut:

$$
\text { INDEP }=\frac{\text { JumlahAnggota Dewan Komisaris Independen }}{\text { JumlahTotal Anggota DewanKomisaris }}
$$




\section{Kompensasi Dewan Komisaris dan Direksi}

Penelitian ini mengikuti Rahayu (2014) yang mengukur kompensasi dengan menggunakan total kompensasi diterima eksekutif selama satu tahun. Penelitian ini mengukur kompensasi eksekutif sebagai total kompensasi, yang mencakup jumlah gaji, bonus, tunjangan, dan pembayaran lain yang diterima eksekutif (Dewan Komisaris dan Direksi) selama satu tahun dibagi dengan revenue perusahaan. Dalam penelitian ini, total kompensasi bagi Dewan Komisaris dan Direksi dilihat dari catatan atas laporan keuangan dan laporan tahunan yang dipublikasi perusahaan. Variabel ini dirumuskan sebagai berikut:

$$
\mathrm{COMB}=\frac{\text { Total yang diterima DewanKomisaris danDireksi }}{\text { RevenuaePerusahaan }}
$$

\section{HASIL DAN PEMBAHASAN}

\section{Hasil Penelitian}

Hasil Pengujian hipotesis untuk membuktikan hasil penelitian yang memiliki pengaruh berdasarkan hipotesis yang telah ditetapkan sebelumnya. Dari tabel di bawah ini dapat dilihat bahwa nilai $\mathrm{R}^{2}$ (koefisien determinasi) adalah sebesar 0.466 yang artinya bahwa analisis hipotesis memberikan penjelasan bahwa Dewan Komisaris, Komisaris Independen, kompensasi Dewan Komisaris dan Direksi, Komite Audit berpengaruh terhadap agresivitas pajak sebesar 40,6\% . hasil output SPSS dibuktikan dalam tabel di bawah ini :

\section{Tabel 1 : Hasil Uji Hipotesis Penelitian}

\begin{tabular}{lcccc}
\hline Keterangan & & & & Nilai \\
\hline R Square & & & & 0.612 \\
Adjusted R Square & & & 0.466 \\
F hitung & & & 4.199 \\
Probabilitas & & & & 0.46 \\
\hline \multirow{2}{*}{ Keterangan } & Unstandardized & Standardized & \multirow{2}{*}{ Uji T } & Probabilitas \\
& Coefficients & Coefficients & & (sig.a 0.05) \\
\hline Constant & 0.179 & & 3.755 & 0.006 \\
DK $\left(X^{1}\right)$ & -0.011 & -1.22 & -2.756 & 0.025 \\
KI $\left(X^{2}\right)$ & 0.381 & 1.075 & 2.097 & 0.069 \\
KOM $\left(X^{3}\right)$ & -2.644 & -0.785 & -2.653 & 0.029 \\
\hline
\end{tabular}

Output SPSS V.22 (2018)

Dari hasil pengujian hipotesis masing-masing secara parsial bahwa variabel penelitian terbukti bahwa Dewan Komisaris berpengaruh terhadap penghindaran pajak sebesar 1,1\%, Komisi Independen sebesar 38,1\% dan kompensasi Dewan Komisaris dan Direksi sebesar $26.44 \%$. 
Hasil pengujian hipotesis secara bersamaan (simultan) bahwa hipotesis dengan nilai Fhitung sebesar 4.199 sedangkan nilai signifikansi F-nya adalah sebesar 0.46 yang artinya bahwa nilai signifikansi $\mathrm{F}$ lebih kecil dari 0.05 maka hipotesis ini membuktikan bahwa, maka hipotesis ini membuktikan bahwa Dewan Komisaris, Komisaris Independen, kompensasi Dewan Komisaris dan Direksi berpengaruh terhadap agresivitas pajak. Dalam model persamaan regresi berganda diformulasikan sebagai berikut :

$$
A G P=0,179-0,011 \mathrm{DK}+0,381 \mathrm{KI}-2,644 \mathrm{KOM}+\epsilon
$$

Keterangan:

1. Nilai konstanta (a) sebesar 0,179 menunjukkan bahwa jika variabel independen sama dengan 0 maka Agresivitas Pajak adalah sebesar 0,179.

2. Koefisien regresi Dewan Komisaris $-0,011$ menyatakan bahwa setiap kenaikan Dewan Komisaris 1 satuan akan diikuti dengan penurunan tindakan agresivitas pajak sebesar 0,011 satuan dengan asumsi variable independen lainnya konstan.

3. Koefisien regresi Komisaris Independen 0,381 menyatakan bahwa setiap kenaikan Komisaris Independen 1 satuan akan diikuti kenaikan tindakan agresivitas pajak sebesar 0,381 satuan dengan asumsi variable independen lainnya konstan.

4. Koefisien regresi kompensasi Dewan Komisaris dan Direksi -2,644 menyatakan bahwa setiap kenaikan kompensasi Dewan Komisaris dan Direksi 1 satuan akan diikuti penurunan tindakan agresivitas pajak sebesar 2,644 satuan, dengan asumsi variable independen lainnya konstan.

\section{Hasil Penelitian dan Pembahasan}

Hasil Adjust $R$ Squere $\left(R^{2}\right)$ sebesar 0,466 atau $46,6 \%$ yang berarti bahwa tindakan agresivitas pajak dapat dijelaskan oleh variasi dari ketiga variabel independen yaitu Dewan Komisaris, Komisaris Independen, dan kompensasi Dewan Komisaris dan Direksi. Sedangkan sisanya $53,4 \%$ dijelaskan oleh variabel-variabel lain yang digunakan di dalam penelitian ini.

\section{Pengaruh Dewan Komisaris Terhadap Tindakan Agresivitas Pajak}

Dari hasil otput SPSS bahwa variabel DK (Dewan Komisaris) memiliki nilai signifikan 0,025 lebih kecil dari $0,05(0,025<0,05)$ dan nilai $t$ - hitung $<$ t-tabel $(-2,731<-2,160)$. Artinya Dewan Komisaris berpengaruh berpengaruh terhadap tindakan agresivitas pajak. Dengan demikian HA diterima dan $\mathrm{HO}$ ditolak. Sehingga dapat disimpulkan $\mathrm{H} 1$ diterima yang artinya secara parsial Dewan Komisaris berpengaruh terhadap tindakan agresivitas pajak pada perusahaan manufaktur sub sektor makanan dan minuman yang terdaftar di bursa efek Indonesia pada tahun 2013-2016.

Hasil penelitian ini sejalan dengan penelitian yang dilakuakan oleh Fahriani dan Priyadi (2016) yang menyebutkan bahwa dewan komisaris berpengaruh terhadap tindakan agresivitas. Hal ini dikarenakan semakin banyak jumlah dewan komisaris dalam perusahaan akan semakin besar pula tindakan pajak agresif yang dilakukan perusahaan.

\section{Pengaruh Komisaris Independen Terhadap Tindakan Agresivitas Pajak}

Variabel KI (Komisaris Independen) memiliki nilai signifikan 0,069 lebih besar dari 0,05 $(0,069>0,05)$ dan nilai t-hitung $<$ t-tabel $(2,097<2,160)$. Artinya bahwa Komisaris Independen tidak berpengaruh terhadap tindakan agresivitas pajak. Dengan demikian HA ditolak dan HO diterima. Sehingga dapat disimpulkan H2 ditolak yang artinya secara parsial Komisaris 
Independen tidak berpengaruh terhadap tindakan agresivitas pajak pada perusahaan manufaktur sub sektor makanan dan minuman yang terdaftar di bursa efek Indonesia pada tahun 2013-2016.

Hasil penelitian ini tidak sejalan dengan Fadli (2013) dan Fahriani dan Priyadi (2016) bahwa Komisaris Independen berpengaruh terhadap tindakan agresivitas pajak. Semakin banyak Komisaris Independen dalam perusahaan maka pengawasan terhadap agen semakin ketat sehingga tidak bisa meminimalisir terhadap tindakan agresivitas pajak.

\section{Pengaruh Kompensasi Dewan Komisaris dan Direksi Terhadap Agresivitas Pajak}

Variabel KOM (Kompensasi Dewan Komisaris dan Direksi) memiliki nilai signifikan 0,029 lebih kecil dari $0,05(0,029<0.05)$ dan nilai t-hitung < t-tabel $(-2,662<-2,042)$. Artinya bahwa Kompensasi Dewan Komisari dan Direksi berpengaruh terhadap tindakan agresivitas pajak. Dengan demikian $\mathrm{HA}$ diterima dan $\mathrm{HO}$ ditolak. Sehingga dapat disimpulkan $\mathrm{H} 3$ diterima, yang artinya secara parsial kompensasi Dewan Komisaris dan Direksi berpengaruh terhadap tindakan agresivitas pajak pada perusahaan manufaktur sub sektor makanan dan minuman yang terdaftar di Bursa Efek Indonesia pada tahun 2013-2015.

Hal ini sejalan dengan penelitian yang dilakukan Rahayu (2014) yang menyebutkan bahwa kompensasi Dewan Komisaris dan Direksi berpengaruh terhadap tindakan agresivitas pajak. Semakin banyak kompensasi yang diterima eksekutif akan mendorong seseorang untuk bekerja karena berpengaruh terhadap moral dan disiplin tenaga sehingga akan meminimalisirkan tindakan agresivitas pajak.

\section{Pengaruh Dewan Komisaris, Komisaris Independen, Kompensasi Dewan Komisaris dan Direksi}

Dari hasil output SPSS di atas menunjukkan hasil uji simultan dengan hasil signifikan 0,047 lebih kecil dari $0,05(0,047<0,05)$ dan nilai F-hitung > F-tabel $(4,196>3,34)$. Hal ini berarti semakin banyak Dewan Komisaris, Komisaris Independen, Kompensasi Dewan Komisaris dan Direksi secara bersama-sama (simultan) maka perusahaan akan cenderung melakukan tindakan agresivitas pajak.

\section{KESIMPULAN DAN REKOMENDASI KEBIJAKAN}

\section{Kesimpulan}

Berdasarkan hasil pengujian data yang diproses SPSS V.22 sesuai dengan tujuan penelitian ini, maka simpulan yang diperoleh dalam penelitian ini yaitu :

1. Dewan Komisaris bepengaruh terhadap tindakan agresivitas pajak pada perusahaan manufaktur sub sektor makanan dan minuman yang terdaftar di Bursa Efek Indonesia periode 2013-2016

2. Komisaris Independen tidak berpengaruh terhadap tindakan agresivitas pajak pada perusahaan manufaktur sub sektor makanan dan minuman yang terdaftar di Bursa Efek Indonesia periode 2013-2016.

3. Kompensasi Dewan Komisaris dan Direksi berpengaruh terhadap tindakan agresivitas pajak pada perusahaan manufaktur sub sektor makanan dan minuman yang terdaftar di Bursa Efek Indonesia periode 2013-2016. 
4. Dewan Komisaris, Komisaris Independen, dan Kompensasi Dewan Komisaris dan Direksi berpengaruh secara-bersama (simultan) berpengaruh terhadap tindakan agresivitas pajak pada perusahaan manufaktur sub sektor makanan dan minuman yang terdaftar di Bursa Efek Indonesia periode 2013-2016.

\section{Rekomendasi Dan Kebijakan}

Berdasarkan hasil interpretasi penelitian ini, maka peneliti memberikan saran sebagai rekomendasi sebagai berikut :

1. Dalam penelitian ini penelitian hanya menggunakan tiga variabel independen dengan durasi penelitian selama 4 tahun. Direkomendasikan untuk penelitian berikutnya peneliti dapat menambah variabel lain dan menambah tahun penelitian, yang memungkinkan untuk mendapatkan hasil yang lebih baik dan akurat.

2. Dalam penelitian ini peneliti menggunakan perusahaan manufaktur pada sub sektor makanan dan minuman, bagi peneliti selanjutnya dapat mengganti objek penelitiannya dengan perusahaan yang lain seperti property dan real estate.

\section{DAFTAR PUSTAKA}

Ardyansyah.2014.Pengaruh Size, Leverage, Prifitability, Capital Intensity, dan Komisaris Independen terhadap Effective Tax Rate (ETR).Jurnal. Universitas Diponegoro

Ariyani.2014.Pengaruh Mekanisme Pengawasan Stakeholder Terhadap Agresivitas Pajak.Skripsi. Universitas Diponegoro Semarang

Fadli.2016.Pengaruh Likuiditas, Leverage, Komisaris Independen, Manajemen Laba, dan Kepemilikan Institusional Terhadap Agresivitas Pajak Perusahaan, Vol.3 No.1 (Februari)

Fahriani dan Priyadi.2016.Pengaruh Corporate Governance Terhadap Tindakan Pajak Agresif Pada Perusahaan Manufaktur, Vol.5 No.7 (Juli)

Ghozali, Imam. 2011. Aplikasi Analisis Multivariate Dengan Program IBM SPSS 19. Semarang: Badan Penerbit Universitas Diponegoro.

Husodo.2017.Pengaruh Likuiditas, Leverage, Profitabilitas, Komisaris Independen dan Ukuran Perusahaan Terhadap Agresivitas Pajak Pada Perusahaan yang Terdaftar di Jakarta Islamic Index Periode 2013-2015.Skripsi. Institut Agama Islam Negeri Surakarta

Mardiasmo.2008. Perpajakan. Yogyakarta: CV. Andi Offseet

Novitasari.2017.Pengaruh Manajemen Laba, Corporate Governance, dan Intensitas Modal Terhadap Agresivitas Pajak Perusahaan, Vol.4 No.1 (Februari)

Peraturan Bursa Efek Inonesia (BEI) nomor Kep-305/BEJ/07-2004 tentang Pencatatan Sahan dan Efek Bersifat Ekuitas Selain Saham yang Diterbitkan oleh Perusahaan Tercatat

Peraturan Otoritas Jasa Keuangan Nomor 33/PJOK.04/2014 tentang Direksi dan Dewan Komisaris Emiten atau Perusahaan Publik 
Pengaruh Dewan Komisaris, Komisaris Independen, Kompensasi Dewan Komisaris

Dan Direksi Terhadap Tindakan Agresivitas Pajak Pada Perusahaan Makanan

Dan Minuman Yang Terdaftar Di Bursa Efek Indonesia Periode 2013-2016

Peraturan Otoritas Jasa Keuangan Nomor 55/POJK.04/2015 tentang Tugas dan Fungsi Dewan Komisaris

Rahayu.2016.Pengaruh Kompensasi Eksekutif, Keterwakilan CFO Wanita,dan Karkteristik Eksekutif Terhadap Tindakan Pajak Agresif.Skripsi. Universitas Islam Negeri Syarif Hidayatullah Jakarta

Sabrina.2013.Analisis Karakteristik Corporate Governance Terhadap Pajak Agresif.Jurnal. Universitas Bina Nusantara Jakarta

Santoso.2014.Pengaruh Corporate Governance Terhadap pengghindaran Pajak Perusahaan. Skripsi. Universitas Diponegoro

Solihin.2017.Pengaruh Karakter Eksekutif Terhadap Tindakan Agresivitas Pajak Dengan Corporate Governance Sebagai Variabel Moderating.Skripsi. Universitas Lampung Bandar Lampung

Surat Edaran PT . Bursa Efek Indonesia SE008/BEJ/12-2001 tanggal 7 Desember 2001 tentang Keanggotaan Komite Audit

Syoraya.2014.Pengaruh Kompensasi Dewan Komisaris dan Dewan Direksi Terhadap Kinerja Manajerial Dengan Risiko Bisnis Sebagai Variabel Moderating.Skripsi. Universitas Dipononegoro Semarang

Undang-Undang No.28 Tahun 2007 tentang Perubahan Ketiga Atas Undang-Undang Nomor 6 Tahun 1983 Tentang Ketentuan Umum dan Tata Cara Perpajakan

Undang-Undang No.36 Tahun 2008 tentang Pajak Penghasilan 